\title{
Effect of Motivational Interviewing Training Program on Compliance among Patients with Substance Use Disorders
}

\author{
Eman Mohamed Eldaghar ${ }^{1}$, Mona Hassan Abdel Aal ${ }^{2}$, Mervet Hossny Shalaby ${ }^{3}$ and Mona \\ Mohamed Barakat ${ }^{4}$
}

(1)Ph.D. student of Psychiatric/Mental Health Nursing, Faculty of Nursing, Benha University, (2) Professor of Psychiatric/Mental Health Nursing, Faculty of Nursing, British University in Egypt, (3) Professor of Psychiatric Mental Health Nursing, Faculty of Nursing, Tanta University and (4) Assistant Professor of psychiatric/Mental Health Nursing, Faculty of Nursing, Benha University

\begin{abstract}
Background: Motivational interviewing empowers the patient's recovery from substance use disorders and compliance with medication and intervention programs adherence. Aim: This study aimed to evaluate the effect of motivational interviewing training program on compliance among patients with substance use disorders. Design: A quasi-experimental research design was used in this study. Setting: This study was conducted at El-abbssia psychiatric mental health hospital at Cairo City \& the psychiatric mental health hospital at Benha city, Qaluobia governorate which are affiliated to secretariat of mental health. Sample: The sample consisted of (60) patients with substance use disorders comprised two matched groups into study group (30) patients and control group(30) patients. Tools of data collection: The data was collected through utilizing the following tools; (1)- structured interview sheet, (2)- readiness to change questionnaire, (3)Motivational interviewing questionnaire and (4)- medication adherence and treatment questionnaire. Results: There were statistically significant improvement in total medication adherence, motivational interview and readiness to change post program implementation among study groups compared with preprogram. Conclusion: Motivational interviewing training program have a positive effect on compliance among patients with substance use disorders and plays an important role in among substance use patients recovery. Recommendations: Continuous in- service training programs about counseling are needed to provide basic necessary skills and apply the motivational interviewing program in addiction centers to provide a better prognosis for substance use disorders.
\end{abstract}

Key words: Compliance, Motivational interviewing, Substance use disorders

\section{Introduction}

Substance Use Disorders (SUD) is the use of a drug or any other substance for nonmedical purpose with the aim of producing some type of mind altering effects in the users. Substance use disorders pose a threat to health, social and economic fabric of families, communities and nations (Fazel et al., 2016).

Treatment modalities for substance use disorders patients, the primary components of comprehensive approach include one on one counseling, cognitive behavioral therapy, motivational enhancement therapy Dialectical Behavior therapy and additional therapy psycho educational groups. Also, medication assisted treatment refers to the combination behavioral interventions and medications to treat substance use (Farag, 2019).

Motivational interviewing is one intervention with some evidence to support its effectiveness in reducing the abuse of substance. Through therapeutic relationship a 
trained counselor with the substance use disorders patients is guided to identify the problem and make decisions about goals for future. In addition, supportive psychosocial therapies have been used as adjuncts to pharmacotherapy and psycho education programs to alleviate residual symptoms, motivational counseling works according to idea that motivation for change by developing a therapeutic relationship to increase therapeutic alliance, coping skills to resolve ambivalence and change health related behavior (Firestone et al., 2015).

Compliance with appropriate recommended, prescribed health treatments; simply means that patients are following a doctor's orders. When combined withcounseling and other behavioral therapies, medications are an essential treatment element for many patients with SUD. Compliance rates reflect the proportion of individuals in treatment who the highest possibility of successful treatment. Noncompliancerates reflect those individuals who have either discontinued or avoided treatment, and thus have lower probabilities of treatment success(Beck, 2018).

Nurse plays a vital role in helping patients undergoing drug rehabilitation through motivating person him to change, Nurses are monitoring their progress, help the patients to adjust to life without drugs and teach them how to maintain their sobriety after leaving rehabilitation, evaluated the ability of patient through use effective coping skills and problem solving, initiate necessary life style changes, engage in peer support, demonstrate active participation in motivational program (Whitesell, 2018).

\section{Significantof the study}

A substance use disorder is a global serious public health concern that affects not only health. Safety\& well-being of communities, but also social \&economic development (World Health Organization Substance Abuse, 2018). In Egypt, Number of drug user of different types at 2018 about $9 \%$ percent, addicted about 3, $9 \%$. Some researches had has pointed out that the painkiller tramadol which illegal to consume without a prescription in Egypt- seemed be the most commonly abused drug, followed by heroin at 26 percent and cannabis at 23, 3 percent. The hotline Egypt supported over 100, 0000 addicts With the help of hospitals and provides free treatment and counseling sessions and helped 37, 244 addicts undergo necessary treatment(Robinson \& Mayer, 2017). This study aimed to evaluate the effect of motivational interviewing training program on compliance among patients with substance use disorders.

\section{Aim of the study}

This study aimed to evaluate the effect of motivational interviewing training program on compliance among patients with substance use disorders.

\section{Research hypothesis:}

Substance user's compliance undergoing motivational interviewing training program will show better enhancement in recovery.

\section{Subject and methods}

\section{Research design:}

A quasi- experimental research design was used in this study.

\section{Research setting:}

The study was conducted at the ElAbbassia Mental Health Hospital at Cairo City and the Psychiatric Mental Health Hospital at Benha City, Qaluobia Governorate which were affiliated to Secretariat of Mental Health. El-Abbassia hospital, addiction department was divided into 2 buildings male 
patients and female patients. The first one for male patients consisted of rehabilitation department which consisted of 10 rooms each room had 6 beds, the second floor detox department which consisted from 5 rooms each room had 6 beds. Another building for female patients which consisted of 4 floors only the third floor was for addictive patient which consisted from 6 rooms each room had 6 beds. At the psychiatric mental health hospital at benha. Addiction department was divided into two departments. The first one detox which was consisted from 2 rooms, every room had 3 beds, the second one for patients' rehabilitation which was consisted from 2 rooms, every room had 3 beds.

\section{Subject}

\section{Type of sample:}

A convenience sample was recruited for study.

\section{Sample size:}

\section{Equation for the sample size n:}

$$
\mathrm{n}=\left(\mathrm{Z}_{\alpha / 2}+\mathrm{Z}_{\beta}\right)^{2} *\left(\mathrm{p}_{1}\left(1-\mathrm{p}_{1}\right)+\mathrm{p}_{2}\left(1-\mathrm{p}_{2}\right)\right) /\left(\mathrm{p}_{1^{-}}\right.
$$

$\left.\mathrm{p}_{2}\right)^{2}$, where $Z_{\alpha / 2}$ is the critical value of the Normal distribution at $\alpha / 2$ (e.g. for a confidence level of $95 \%, \alpha$ is 0.05 and the critical value is 1.96$), Z_{\beta}$ is the critical value of the Normal distribution at $\beta$ (e.g. for a power of $80 \%, \beta$ is 0.2 and the critical value is 0.84) and $\mathrm{p}_{1}$ and $\mathrm{p}_{2}$ are the expected sample proportions of the two group. Both group fulfilled the following criteria(Chow, et al ., 2017).

The sample consisted of 60 substance disorders patients'comprised two matched groups into study (30) and control group (30). Patients in both groups received their regular treatment, but only those in study group received the motivational interviewing training program.

\section{Inclusion criteria:}

-Willingness to participate in the study.

- Age above 18 years old.

- Patient at rehabilitation or at recovery stage.

\section{Exclusion criteria:}

- Patients with psychiatric disorders or medical illness.

\section{Tools for data collection:}

The data was collected through utilizing the following tools:

\section{Tool (1): structured Interview sheet:}

This tool was developed by the researcher based on scientific review of literature which divided into two parts.

- Part one: Socio-demographic data: To elicit data about the patient's characteristics such as age, sex, level of education, marital status, occupation, income, residence \&hospital

- Part two: Clinical data: This includes patient's history about age at started substance use, Times of substance use, the period of drug use, method of admission.

\section{Tool (2): readiness to Change} Questionnaire, This scale was developed by Rollnick et al., (1992). This tool adapted by researcher and items adapted and modification from 30 items to 18 items. This was used to evaluate readiness to change among substance use disorders patients. In this tool fine reverse questions as question (q1, 7, 12, 14 \&15).

\section{Scoring system:}

The scoring system for readiness to change questionnaire include five point rating scale which provides a range of five response options utilized to measure each of items for way that people may feel about their substance use disorder. The five point scales are scored as follows; strongly disagree $=0$, 
Disagree $=1, \quad$ Unsure $=2, \quad$ Agree $=3 \&$ strongly agree $=4$.

$><50 \%=<18$ score indicates low degree.

$>50-75 \%=18-54$ score indicates moderate degree.

$>>75 \%=>54$ score indicates high degree.

Tool (3): motivational Interviewing questionnaire:-

\section{Scoring system:-}

This scale was developed by the researcher; it is consisted of 29 items which used to measure readiness to motivational interviewing among substance abuse patients. This tool adapted by the researcher. The three point scale as the following; $\mathrm{No}=0$, to some extent $=1 \&$ yes $=2$

$><50 \%=<29$ score indicates low degree.

$>50-75 \%=29-44$ score indicates moderate degree.

$>75 \%=>44$ score indicates high degree

\section{Tool (4):medication adherence and treatment questionnaire}

\section{Scoring system:-}

This scale was developed bythe researcher, it is consisted of 21 questions which was used to medication adherence and treatment programs. This tool adapted by the researcher and items adapted and modification from 30 items to 21 items, the three point scale as the following; $\mathrm{No}=0$, to some extent $=1 \&$ yes $=2$.

$<50 \%=<21$ score indicates low degree.

$>50-75 \%=21-42$ score indicates moderate degree.

$>75 \%=>42$ score indicates high degree

\section{Content validity}

The revision of tools was done by five of expertise in mental health nursing and medicine specialties to measure validity of tools and elicited regarding the format; lay out, consistency, accuracy and relevancy of the tools.

\section{Tools reliability:}

\begin{tabular}{|l|c|c|}
\hline \multicolumn{1}{|c|}{ Items } & $\begin{array}{c}\text { Number } \\
\text { of items }\end{array}$ & $\begin{array}{c}\text { Cronbach } \\
\text { Alpha } \\
\text { coefficient }\end{array}$ \\
\hline $\begin{array}{l}\text { 1. Readiness of } \\
\text { change scale }\end{array}$ & 18 & 0.670 \\
\hline $\begin{array}{l}\text { 2. Medication and } \\
\text { adherence of } \\
\text { Treatment scale }\end{array}$ & 21 & 0.675 \\
\hline $\begin{array}{l}\text { 3. Role } \\
\text { motivational } \\
\text { interviews scale }\end{array}$ & 0.752 \\
\hline
\end{tabular}

\section{Pilot study}

A pilot study was conducted on $10 \%$ (6) of patients before embarking in the field of work to ascertain the clarity and applicability of the study tools, identify the time needed to them, availability of the sample, and perform the required modification according to the available resources, the patients who included in pilot study, were excluded from the main study sample.

\section{Data collection}

Datacollection of this study was being carried out at psychiatric mental health hospital at Benha, Qaluobia Governorate and from El-Abbassia psychiatric mental health hospital at Cairo governorate. The data was done on both control and study groups.

\section{Assessment phase:-}

During this phase, the researchers meet the study subject individually for the initial assessment. Consent was obtained from each patient after the explanation the purpose of the study. Baseline data for both groups such as age, education, marital status, residence, occupation, past history, treatment, and 
family history. Each interviewed last about 25-30 minutes.

\section{Planning and development phase:}

During this phase the researcher developed psycho-educational intervention program according to pretest assessment by using tools I and II and review of related literature.

\section{Field work:}

Motivational interviewing training program for the study group (30 patients with substance use disorders). This group was divided into 4 groups about 7 to 8 patients in each group. The session of motivational interviewing training program with study group was carried out during the period from $1{ }^{\text {st }}$ October, 2019 to $1^{\text {st }}$ January, 2020. Each session last approximately 60 to120 minutes /days for 2 days in One week, total sessions for studying groups need 5 months. Posttest for study group is only after the program implementation from $1^{\text {st }}$ Fabuary, 2020 to $30^{\text {th }}$ Fabuary, 2020, The program consists 14 session.

\section{Implementation phase:}

This phase was begin by data collection then implementation of training program for all substance use disorders patients who meet the previously mentioned inclusion criteria during the study period. Data collection of this study was carried out at El-Abbassia psychiatric mental health hospital at Cairo governorate and the psychiatric mental health hospital at Benha city, Qaluobia governorate.

\section{Evaluation phase (post-test):}

This phase aimed to estimate the effect of motivational interviewing training program on compliance among substance use disorders patients. After conducting of the training program for the study sample, posttest was done using the study tools. Also, a post-test was done for the control group after a period of time.

\section{Ethical considerations:}

1- Verbal approval was obtained from the patients before inclusion in the study

2- A clear and simple explanation was given according to their level of understanding physical and mental readiness. Research approval was obtained from the faculty ethical committee before starting the study

2- Clarified the objectives and aim of the study to the patients included in the study before starting. Patients were informed that they are allowed to choose to participate or not in the study and they had the right to withdraw from the study at any time.

\section{Statistical analysis:}

Statistical data entry and analysis were done using SPSS version 19 Statistical software pakage of social science. Data were presented using descriptive statistics in the form of frequencies, percentages for qualitative variables, medians for qualitative variables, means and standard deviations. Cronbach alpha coefficient was calculated to assess reliability of the developed tools through their internal consistency. Qualitative categorical variables were compared using tests, independent sample, t-test analysis of variance, an ova (f test) and person correlation coefficient used to compare the relation between study variables.

\section{Limitation or difficulties of the study}

All patients in study \&control groups were males. In psychiatric mental hospital at Banha all male patients come during period of program implementation, no female patients in inpatient or in outpatient and the same thing at El-Abbssia psychiatric hospital. But find female addiction unit but manger doctors 
refuse inside this unit and notify me that patients not share in this study.

\section{Results}

Table (1) Reveals that, $40 \%$ control group \& $43.33 \%$ of study group) within age group 28-<38 years, with $\mathrm{M} \pm \mathrm{SD} 31.67 \pm$ 7.76 for control group while, $34.67 \pm 8.78$ for study group. The result shows that also that $53.33 \%$ were married. Concerning to education level, about $33.33 \%$ of control group \& $26.67 \%$ of study group had secondary educational level, concerning to occupation $80 \%$ of study group \& $70 \%$ of control group was working. Regarding to monthly income, control group $40 \%$ their monthly income insufficient \& $50 \%$ study group also their monthly income insufficient the result shows also that the majority of the control group $83.33 \%$ from urban, while more than half $53.33 \%$ of study group from urban.

Table (2) show that, (study \& control groups) $86.67 \& 76.67 \%$ respectively their ago at starting of drug use within age group 18$<28$ years. Regarding to times of drug use control group $50 \% \& 40 \%$ of studying group had 3-7 times of drug use. The result also reveals $76.67 \%$ of control group \& $60 \%$ of study group their period of drug use 5 years or more. Concerning to admission method, (control \& study group $93.33 \%$ \& $73.33 \%$ respectively admitted involuntary, $66.67 \%$ of control group have family addict to drug, while $40.87 \%$ of study group hadn't family addict to drugs $40 \% \& 93.33 \%$ of the studied sample (control \& study) groups respectively have relatives addict to drugs. The result also illustrates that $76.67 \%$ \& $73.33 \%$ of control\& study groups respectively have family supported.

Table (3) clarifies that, there was no statistical significant difference of motivational interview scale among control group pre and post program, implementation, while there was a highly significant improvement of motivational interview questionnaire among study group post program implementation at $\mathrm{P}=<0.01$ compared to preprogram implementation.

Table (4) reveals that, there was no statistical significant difference of medication adherence among control group pre and post program implementation but there was a highly statistical significant improvement of medication adherence among study group pre and post program implementation at $\mathrm{P}<0.001$ compared to preprogram.

Table (5) clarifies that, there was no statistical significant difference of readiness to change level among control groups pre and post program, while there was a highly statistical significant improvement of readiness to change among study group pre and post program implementation at $\quad(\mathrm{P}=$ $<0.00)$ compared to preprogram implementation.

Figure (1) this figure shows that, there was a marked improvement in the total mean scores of readiness to change, medication adherence, and motivational interviews questionnaires post program implementation among study group compared to preprogram implementation

Table (6) show that, there was statistical significant positive correlation between medication adherence and readiness to change at ( $\mathrm{p}$ value $=<0.05$ ). While there was a highly statistically significant positive correlation between totalmotivational interview questionnaire and readiness to change questionnaire, Alsototal medication adherence and motivational interview questionnaire among the study group at $(\mathrm{p}$ value $=<0.000)$ post program implementation. 
Table (1): Distribution of the studied (control\& study groups) according to their socio demographic characteristics

\begin{tabular}{|c|c|c|c|c|c|c|}
\hline \multirow[t]{2}{*}{ Socio-demographic } & \multicolumn{2}{|c|}{$\begin{array}{l}\text { Control group } \\
(\mathbf{N}=\mathbf{3 0})\end{array}$} & \multicolumn{2}{|c|}{$\begin{array}{l}\text { Study group } \\
\qquad(\mathbf{N}=\mathbf{3 0})\end{array}$} & \multicolumn{2}{|c|}{$\begin{array}{c}\text { Total } \\
(\mathrm{N}=60)\end{array}$} \\
\hline & No & $\%$ & No & $\%$ & No & $\%$ \\
\hline Age(years) & & & & & & \\
\hline 18 & 11 & 36.67 & 7 & 23.33 & 18 & 30.00 \\
\hline 28 & 12 & 40.00 & 13 & 43.33 & 25 & 41.67 \\
\hline$>38$ & 7 & 23.33 & 10 & 33.33 & 17 & 28.33 \\
\hline Mean \pm SD & \multicolumn{2}{|c|}{$31.67 \pm 7.76$} & \multicolumn{2}{|c|}{$34.67 \pm 8.78$} & \multicolumn{2}{|c|}{$33.17 \pm 8.33$} \\
\hline Gender & & & & & & \\
\hline -Male & 30 & 100.00 & 30 & 100.00 & 60 & 100.00 \\
\hline \multicolumn{7}{|l|}{ Marital status } \\
\hline -Married & 17 & 56.67 & 15 & 50.00 & 32 & 53.33 \\
\hline - Single & 13 & 43.33 & 15 & 50.00 & 28 & 46.67 \\
\hline \multicolumn{7}{|l|}{ Educational level } \\
\hline - Illiterate & 3 & 10.00 & 5 & 16.67 & 8 & 13.33 \\
\hline -Read and write & 8 & 26.67 & 8 & 26.67 & 16 & 26.67 \\
\hline -Preparatory & 5 & 16.67 & 7 & 23.33 & 12 & 20.00 \\
\hline -Secondary & 10 & 33.33 & 8 & 26.67 & 18 & 30.00 \\
\hline -University & 3 & 10.00 & 2 & 6.67 & 5 & 8.33 \\
\hline -Post graduate & 1 & 3.33 & 0 & 0.00 & 1 & 1.67 \\
\hline \multicolumn{7}{|l|}{ Occupation } \\
\hline -Not working & 9 & 30.00 & 6 & 20.00 & 15 & 25.00 \\
\hline -Working & 21 & 70.00 & 24 & 80.00 & 45 & 75.00 \\
\hline \multicolumn{7}{|l|}{ Monthly income } \\
\hline -Sufficient & 11 & 36.67 & 13 & 43.33 & 24 & 40.00 \\
\hline -In-sufficient & 12 & 40.00 & 15 & 50.00 & 27 & 45.00 \\
\hline -Sufficient and spare & 7 & 23.33 & 2 & 6.67 & 9 & 15.00 \\
\hline \multicolumn{7}{|l|}{ Residence } \\
\hline -Rural & 5 & 16.67 & 14 & 46.67 & 19 & 31.67 \\
\hline -Urban & 25 & 83.33 & 16 & 53.33 & 41 & 68.33 \\
\hline \multicolumn{7}{|l|}{ Hospital } \\
\hline -El-Abbsia Hospital & 15 & 50.00 & 15 & 50.00 & 30 & 50.00 \\
\hline $\begin{array}{l}\text {-Psychiatric Mental } \\
\text { - Benha hospital }\end{array}$ & 15 & 50.00 & 15 & 50.00 & 30 & 50.00 \\
\hline
\end{tabular}


Table (2): Distribution of the studied groups (control \&study) according to clinical characteristic

\begin{tabular}{|c|c|c|c|c|c|c|}
\hline \multirow[t]{2}{*}{ Clinical data } & \multicolumn{2}{|c|}{$\begin{array}{l}\text { Control } \\
\text { Group } \\
(\mathrm{N}=30)\end{array}$} & \multicolumn{2}{|c|}{$\begin{array}{l}\text { Study group } \\
\qquad(\mathbf{N}=\mathbf{3 0})\end{array}$} & \multicolumn{2}{|c|}{$\begin{array}{c}\text { Total } \\
(\mathrm{N}=60)\end{array}$} \\
\hline & No & $\%$ & No & $\%$ & No & $\%$ \\
\hline $\begin{array}{l}\text { 1-Age at started drug } \\
\text { use(years) } \\
18-<28 \\
>28\end{array}$ & $\begin{array}{c}26 \\
4\end{array}$ & $\begin{array}{l}86.67 \\
13.33\end{array}$ & $\begin{array}{c}23 \\
7\end{array}$ & $\begin{array}{l}76.67 \\
23.33\end{array}$ & $\begin{array}{l}49 \\
11\end{array}$ & $\begin{array}{l}81.67 \\
18.33\end{array}$ \\
\hline $\begin{array}{l}\text { 2-Times of drug use of drug } \\
\text { use taking(Week) } \\
\text { 1-3times } \\
\text { 4-6times } \\
\text { 3-7times }\end{array}$ & $\begin{array}{c}10 \\
5 \\
15\end{array}$ & $\begin{array}{l}33.33 \\
16.67 \\
50.00\end{array}$ & $\begin{array}{c}11 \\
7 \\
12\end{array}$ & $\begin{array}{l}36.67 \\
23.33 \\
40.00\end{array}$ & $\begin{array}{l}21 \\
12 \\
27\end{array}$ & $\begin{array}{l}35.00 \\
20.00 \\
45.00\end{array}$ \\
\hline $\begin{array}{l}\text { 3-The period of drug } \\
\text { use(years) } \\
1-2 \\
3-4 \\
5 \text { or more }\end{array}$ & $\begin{array}{c}1 \\
6 \\
23\end{array}$ & $\begin{array}{c}3.33 \\
20.00 \\
76.67\end{array}$ & $\begin{array}{c}3 \\
9 \\
18\end{array}$ & $\begin{array}{l}10.00 \\
30.00 \\
60.00\end{array}$ & $\begin{array}{c}4 \\
15 \\
41\end{array}$ & $\begin{array}{c}6.67 \\
25.00 \\
68.33\end{array}$ \\
\hline $\begin{array}{l}\text { 4-Method of admission } \\
\text {-Voluntary } \\
\text {-Involuntary }\end{array}$ & $\begin{array}{c}2 \\
28\end{array}$ & $\begin{array}{c}6.67 \\
93.33\end{array}$ & $\begin{array}{c}8 \\
22\end{array}$ & $\begin{array}{l}26.67 \\
73.33\end{array}$ & $\begin{array}{l}10 \\
50\end{array}$ & $\begin{array}{l}16.67 \\
83.33\end{array}$ \\
\hline $\begin{array}{l}\text { 5-Is there anyone in the } \\
\text { family addict? } \\
\text {-Yes } \\
\text {-No }\end{array}$ & $\begin{array}{l}20 \\
10\end{array}$ & $\begin{array}{l}66.67 \\
33.33\end{array}$ & $\begin{array}{l}14 \\
16\end{array}$ & $\begin{array}{l}46.87 \\
53.33\end{array}$ & $\begin{array}{l}34 \\
26\end{array}$ & $\begin{array}{l}56.67 \\
43.33\end{array}$ \\
\hline $\begin{array}{l}\text { 6-If the answer is yes:- } \\
\text { What's your relation with } \\
\text { them? } \\
\text {-Father } \\
\text {-Sister or brother- } \\
\text {-Relatives }\end{array}$ & $\begin{array}{c}4 \\
12 \\
12\end{array}$ & $\begin{array}{l}13.33 \\
40.00 \\
40.00\end{array}$ & $\begin{array}{c}3 \\
11 \\
13\end{array}$ & $\begin{array}{l}10.00 \\
36.67 \\
43.33\end{array}$ & $\begin{array}{c}7 \\
23 \\
25\end{array}$ & $\begin{array}{l}11.67 \\
38.33 \\
41.67\end{array}$ \\
\hline $\begin{array}{l}\text { 7-Is there anyone from your } \\
\text { family support for you? } \\
\text {-Yes } \\
\text {-No }\end{array}$ & $\begin{array}{c}23 \\
7\end{array}$ & $\begin{array}{l}76.67 \\
23.33\end{array}$ & $\begin{array}{c}22 \\
8\end{array}$ & $\begin{array}{l}73.33 \\
26.67\end{array}$ & $\begin{array}{l}45 \\
15\end{array}$ & $\begin{array}{l}75.00 \\
25.00\end{array}$ \\
\hline
\end{tabular}


Table (3): Distribution of studied sample (control\& study groups) according to their medication adherence questionnaire pre \& post program implementation

\begin{tabular}{|c|c|c|c|c|c|c|c|c|c|c|c|c|c|c|}
\hline \multirow{3}{*}{$\begin{array}{c}\text { Total } \\
\text { Medication adherence scale }\end{array}$} & \multicolumn{6}{|c|}{ Preprogram $(n=30)$} & \multicolumn{6}{|c|}{ Post program $(n=30)$} & \multirow{3}{*}{$\mathbf{X}^{2}$} & \multirow{3}{*}{ P Value } \\
\hline & \multicolumn{2}{|c|}{ Low } & \multicolumn{2}{|c|}{ Moderate } & \multicolumn{2}{|c|}{ High } & \multicolumn{2}{|c|}{ Low } & \multicolumn{2}{|c|}{ Moderate } & \multicolumn{2}{|c|}{ High } & & \\
\hline & $\mathbf{N}$ & $\%$ & $\mathbf{N}$ & $\%$ & $\mathbf{N}$ & $\%$ & $\mathbf{N}$ & $\%$ & $\mathbf{N}$ & $\%$ & $\mathbf{N}$ & $\%$ & & \\
\hline Control Group $(n=30)$ & 17 & 56.7 & 10 & 33.3 & 3 & 10 & 15 & 50 & 11 & 36.7 & 4 & 13.3 & 1.303 & .068 \\
\hline Study Group $(n=30)$ & 19 & 63.3 & 8 & 26.7 & 3 & 10 & 5 & 16.7 & 13 & 43.3 & 12 & 40 & 8.316 & $.001 * *$ \\
\hline
\end{tabular}

**Highly significant $<0.01$.

Table (4): Distribution of studied sample (control \& study groups) according to their motivational interviews questionnaire pre $\&$ post program implementation

\begin{tabular}{|c|c|c|c|c|c|c|c|c|c|c|c|c|c|c|}
\hline \multirow{3}{*}{ Total Motivational scale } & \multicolumn{6}{|c|}{ Preprogram $(n=30)$} & \multicolumn{6}{|c|}{ Post program $(n=30)$} & \multirow{3}{*}{$\mathbf{X}^{2}$} & \multirow{3}{*}{ P Value } \\
\hline & \multicolumn{2}{|c|}{ Low } & \multicolumn{2}{|c|}{ Moderate } & \multicolumn{2}{|c|}{ High } & \multicolumn{2}{|c|}{ Low } & \multicolumn{2}{|c|}{ Moderate } & \multicolumn{2}{|c|}{ High } & & \\
\hline & $\mathbf{N}$ & $\%$ & $\mathbf{N}$ & $\%$ & $\mathbf{N}$ & $\%$ & $\mathbf{N}$ & $\%$ & $\mathbf{N}$ & $\%$ & $\mathbf{N}$ & $\%$ & & \\
\hline Cont & 12 & 40 & 14 & 46.7 & 4 & 13.3 & 10 & 33.3 & 14 & 46.7 & 6 & 20 & 2.357 & $.048 *$ \\
\hline Study Grou & 11 & 36.7 & 17 & 56.7 & 2 & 6.7 & 5 & 16.7 & 10 & 33.3 & 15 & 50 & 9.004 & $.001 * *$ \\
\hline
\end{tabular}

*significant $<0.05$

**Highly significant $<0.01$.

Tables (5): Distribution of studied sample control \& study groups according to their readiness to change pre \& post program implementation

\begin{tabular}{|c|c|c|c|c|c|c|c|c|c|c|c|c|c|c|}
\hline \multirow{3}{*}{$\begin{array}{l}\text { Total } \\
\text { readiness to change scale }\end{array}$} & \multicolumn{6}{|c|}{$\begin{array}{l}\text { Preprogram } \\
\quad(n=30)\end{array}$} & \multicolumn{6}{|c|}{$\begin{array}{l}\text { Post program } \\
\quad(n=30)\end{array}$} & \multirow{3}{*}{$\mathbf{X}^{2}$} & \multirow{3}{*}{ P Value } \\
\hline & \multicolumn{2}{|c|}{ Low } & \multicolumn{2}{|c|}{ Moderate } & \multicolumn{2}{|c|}{ High } & \multicolumn{2}{|c|}{ Low } & \multicolumn{2}{|c|}{ Moderate } & \multicolumn{2}{|c|}{ High } & & \\
\hline & $\mathbf{N}$ & $\%$ & $\mathbf{N}$ & $\%$ & $\mathbf{N}$ & $\%$ & $\mathbf{N}$ & $\%$ & $\mathbf{N}$ & $\%$ & $\mathbf{N}$ & $\%$ & & \\
\hline Control Group $(n=30)$ & 18 & 60 & 10 & 33.3 & 2 & 6.7 & 14 & 6.7 & 12 & 40 & 4 & 13.3 & 1.244 & .064 \\
\hline Study Group $(n=30)$ & 19 & 63.3 & 8 & 26.7 & 3 & 10 & 6 & 20 & 9 & 30 & 15 & 50 & 9.465 & $.000 * *$ \\
\hline
\end{tabular}

$* *$ Highly significant $<0.01$.

Study group

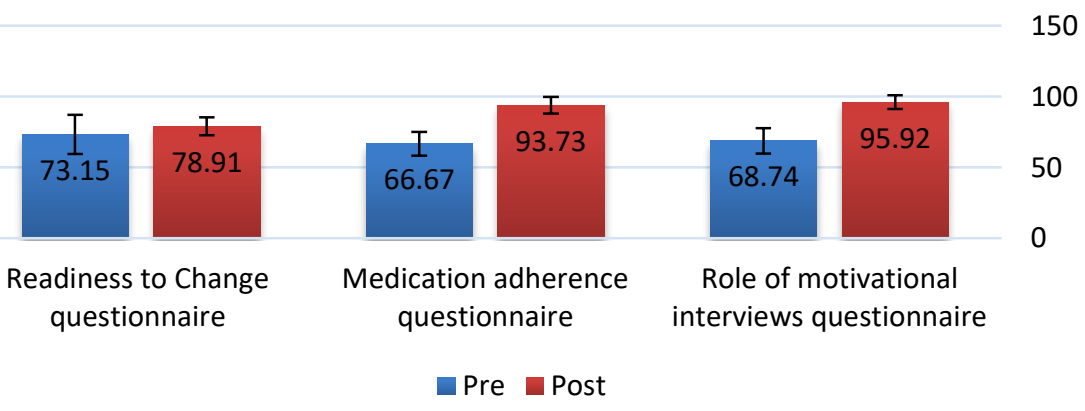

Figure (1): Total means scores of readiness to change, medication adherence and motivational interviews questionnaires among study group pre \& post program implementation 
Table (6): Correlation between total readiness to change, medication adherence and motivational interview among study group post program implementation

\begin{tabular}{|c|c|c|c|c|}
\hline \multirow{2}{*}{ Scales } & \multicolumn{4}{|c|}{ Study group (n=30) } \\
\cline { 2 - 5 } & \multicolumn{3}{|c|}{ Readiness to change } & \multicolumn{2}{c|}{ Medication adherence } \\
\cline { 2 - 5 } & r. & p. & r. & p. \\
\hline $\begin{array}{c}\text { Readiness to } \\
\text { changequestionnaire }\end{array}$ & & & .299 & $.018^{*}$ \\
\hline $\begin{array}{c}\text { Motivationalinterviewquestion } \\
\text { naire }\end{array}$ & .681 & $.000^{* *}$ & .592 & $.000^{* *}$ \\
\hline
\end{tabular}

*significant $<0.05$

\section{Discussion}

Motivational interviewing is the most successfully disseminated evidence based practice in substance use. Motivational interviewing attempts to increase the client's awareness of the potential problems caused, consequence experienced, and a risk faced as a result of their behavior, focuses on the present, and entails working with a client to access motivation to change client motivation articular behavior that is not consistent with a client's personal value or goal. The main goals of motivational interviewing are to engage clients, elicit talk, and evoke to make positive changes (Doostain et al., 2019). This study aimed to assess Effect of motivational interviewing training program on compliance among patients with substance use disorders.

Regarding to sociodemographic \& clinical characteristic of studied sample (control \& study group). The present study revealed that, less than half of the total studied patients (control \& study) their ages ranged from 28 to less than 38 years with mean age $33.17 \pm 8.33$. This result may be due to lack of interpersonal skills for this age group to cope with daily life stressors such as establishment of career, lack of involvement in more productive work, lack of meaningful goal for life in the absence of future plan, limited financial resources, inability to meet demands of marriage, failure to find satisfying

\section{$* *$ Highly significant $<\mathbf{0 . 0 1}$.}

job, lack of sense of meaning, lack of mutual relationship, lack of protective housing, and loss of family or social support.

This result is in agreement with Farag, (2019) who found that, half of the substance use disorders patients were married, also this result is in agreement withAbd Elhamid, (2018)mentioned that the majority of their studied participants were married. This result is in disagreement with Homel et al. (2015), indicated that most of substance use patients ignore the marriage plan for increasing their withdrawal from social contact in order to keep privacy in practicing the addictive behaviors, avoid responsibilities and criticism from other spouse or reduce behavioral limitations.

The result of present study reveals that, all of the study sample was males. This result may be due to that male patients face daily life stressors, most of them escapes from this stress through consuming addictive drugs or other substance use, also, lack of coping strategies, lack of orientation about urgent management techniques, and lack of effective dealing with high risk situations and environmental triggers can produce urges and craving to substance use disorders compared with woman. Additionally, Egyptian culture prevents women from become addicted so, women rarely become substance abusers. 
This result is supported by Karriker et al. (2018) who explained that men are more likely substance use disorders than woman, Egyptian culture conceptualize female substance abusers as deviant, guilty, impulsive, easily irritable, less emotionally stable, and less resistant to life stressors. So, they avoid any involvement in follow up services that increase chances of their relapse. This result disagrees with Kaur\&Ajinkya, (2017), who found that women are treated from substance use disorders more frequently than men.

In relation to marital status, finding of the current study reveals that, more than half of the total studied patients were married. This result may be due to that most of the studied patients at the age group from 28 to $<38$ years were married and have many obligations and responsibilities such as supporting their families, these responsibilities may expose them to negative trend that may lead to substance use disorders and destroy their life completely but the single person has little obligations and there is no pressure or burden on him.

This result is in agreement with Farag, (2019) who found that, half of the substance use disorders patients were married. This result is in disagreement with Homel et al. (2015), indicated that most of substance use patients ignore the marriage plan for increasing their withdrawal from social contact in order to keep privacy in practicing the addictive behaviors, avoid responsibilities and criticism from other spouse or reduce behavioral limitations.

In relation to the educational level, results of the present study revealed that, about one third of the total studied patients graduated from secondary school. This result may be due to the fact that peer pressure can exert substance use disorders through modeling the addictive behaviors of deviant others and promote attitude that encourage substance use and stimulating substance use disorders temptation particularly among secondary school students for several reasons such as being attractive in the view of peers to be follower among peer group. This result agreed with Cleary \& Thoms, (2017) who stated that about two thirds of the participants reported that secondary education increased substance use disorders, students who delay enrollment have higher levels of substance use disorders and may be particularly vulnerable to long term substance use problems.

Regarding to occupation, results of the present studied revealed that three quarters of the total study patients suffer many substance use disorders, working. This may be due to the need for work to overcome all responsibilities; also, the areas of work are contributing to substance use because stressors and work group culture that substance enhances work performance and productivity. These results agree with Ali (2018) who mentioned that nearly two thirds of the studied patients were worked.

Regarding monthly income, the result of the present study revealed that, less than half of the total studied patients had insufficient monthly income this result may be due to the fact that substance use disorders dependency affects productivity and their ability to work beside family responsibility. So, monthly income insufficient to cover life requirements of food eating, drinking and clothing, and cost of substance use. This result agreed with Reitan, (2018)who reported that low income group was burdened in terms of finances, disruption of family routine, and family interaction, as well as mental health of family members. This finding is in disagreement 
with Ali, (2018) who stated that majority of studied samples had enough income.

Regarding to residence, the result of the current study revealed that, about two thirds of total studied (control\& study groups) patients were urban residents. This result may be due to that most of the studied patients' ages ranged from $(28-<38)$, in these age group, characteristic of the deviation and stealing in urban is more common, life in cities is completely different from rural life than life in urban and person seek to know things that leave the customary laws as substance use disorders when compared with rural the cultures and interactions are limited.

This result is in agreement with Pullen \& Oser, (2014) reported that, spread of poverty in rural area was related to lack of needs for substance, so people need money for overcome their burden of daily life requirements when compared with people in urban need for substance use for face daily stressors and families, so they escape from these burden and stress by addict substance or drugs.

Concerning to age at the starting of substance use disorders, the present study reveals that, most of the total studied patients started substance use disorders between age $(18-<28)$ years. This result may be due to patient in this aged group become mature and inter in relation as friends and other substance use disorders that impact them negatively in the form of life stressors, negative emotions as tension, impulsivity, anxiety due to stressful life events as loss of job and lack of financial resources, lack of social support, and separation from spouse.

This result is in agreement with Farag, (2019) mentioned that, the majority of the studied sample abused substance disorders between $(18-<29)$ years.
In relation to times of substance use disorders, the result of the present study revealed that less than half of total studied patient's substance use disorders $\geq 7$ times. This result may be due to the fact that this age person faces stressors, so patients use substance to get rid of this burden. Patients interact with bad friends and stay more time with bad friends together using addictive substance use. When patients suffer from substance use disorders they need to take substance use several times daily until they feel euphoric mood then they takes a long period of treatment to recovery. This result is in agreement with Crane et al. (2016)found that, lack of power, bad friends, stress, economic pressures, lacked of social adjustment, and lack self-esteem lead patients to taking abuse more times per day.

Concerning period of substance abuse, this study clarified that, more than two thirds of studied patients their duration of substance abuse was around 5 years. This result may be due to exposure to continuous substance use several times daily and body gets used to substance use and changes from several times daily to years. Many patients relapse to substance use due to their exposure to conflicting home, lack of secure attachment, low self-esteem and inability to cope effectively with stressors. These result were similar to those of the study done by Farag, (2019) found that, more than half of the studied samples abused from $(5<10)$ years. While this result was in disagreement with Abd Elhamid, (2018)mentioned that the substance abusers were abused between 10 to $<15$ years old.

Regarding readiness to change level among the study group, the result of present study revealed that, there was highly significant improvement of readiness to change post program in study group (substance use 
disorders patients) compared to control group. This result may be due to high level of change among substance use disorders patient because engage in activities that have long term positive effects on mood, health and coping such as engaging in any type of exercise or social activities and teach individuals who trying to change their behavior and thinking cope with the problem this leads to increase self-efficacy, developed through experience of positively coping with high risk situation.

This study agreed with Miller et al. (2016) reported that, many patients' motivation to change behavior is a crucial factor in the success of behavioral and cognitive-behavioral interventions, in line with reasoning, motivational interviewing is treatment strategy that capitalizes on the ability of therapists to increase patient's motivation to change behavior. This result is in disagreement with Al- Ruwaili \& Alshawi, 2016; Abu Attia \& El-Hassan, (2014)mentioned that there was no statistical significant improvement of readiness to change among the study group.

Regarding to medication adherence, the result of present study revealed that, a highly statistical significant improvement among study group post program compared to control group, there was no statistical significant difference or improvement. This finding may be due to patient responds better when a therapeutic plan or therapy had a positive effect on compliance with medication and treatment programs and changes his or her lifestyle.

This result agrees with Volkow et al. (2016) reported that brief educational program focus on treating substance use disorders and describes which patient correctly follows medical advice, self exercises and therapy session can help patients' compliance or adherence. This result was in accordance with Al-Mshaqbh (2015)found that motivational interview training program was effective in improving adherence to medication and reducing addiction behavior and there was a marked increase in all items post intervention than pre intervention.

Regarding motivational interview, the result of study group revealed that highly significant improvement among the motivational interview post program compared to control group there was no statistical significant. This result may be due to substance use disorders patients become motivate after program. Through therapeutic a trained counselor the substance use disorders patients to identify his or her problems and make decisions about goals for future and become better after program take this result due to the effect of the several activities applied through the motivational interviewing sessions which increased clients' insight in their abilities and limitations.

This study showed that there is a highly significant improvement observed in patient's motivational interview after program, as patients showed self-efficacy months after trusted people about their problems, being more self-confident in actual abilities, and accepting and follow implementation of motivational interviewing sessions.

This result agreed with Limberger \& Andretta, (2018), clarified that, motivational interviewing involves using of change active listening; reflecting motivates patients to change bad habits and improvement. In the same direction, Morre \& Fine, (2015) stated that stresses management skills can be an effective component of motivational interviewing for addict patient. 
Regarding the correlation between medication adherence and readiness to change at post motivational program, the current study result demonstrated that there was a significant positive correlation between total of medication adherence and total readiness to change post motivational interviewing program, this indicates that improvement of medication adherence accompanied with positive result of readiness to change. This result may be due to that patient who adherence to medication able to change bad habits and lifestyles. While there is a highly statistically positive correlation between total motivational interview, medication adherence and readiness to change, this indicates that as improvement of medication adherence and motivation accompanied with higher positive result of readiness to change. This result may be due to technique used in the motivational interviewing program motivate him for recovery, help patient for change negative behavior and correct it.

This result is in agreement with Hedari \& Ghodusi, (2016)stated that there was a statistically significant positive correlation between total medication adherence and readiness to change \& highly statistically significant positive correlation between total motivational interview readiness to change and medication adherence.

This result was supported by Neale et al., (2016) stated that the effect of motivational interviewing program for helped the patients identify their actual problems and adapt with life without substance and activates, and program helped the patients to learn the importance of change, finding proper and suitable alternative to satisfy their needs and occupy their time by useful means, clarifying the importance of different community and personal values. The study revealed that, there was a statistical significant relation between ages; occupation $\&$ residence of the study group and total mean scores of readiness to change. Also, a highly statistical significant relation between educational level and income.

\section{Conclusion}

Motivational interviewing training program had positive effecton compliance among patients with substance use disorders. There was a marked improvement inreadiness to change, medication adherence and motivational interviews questionnaire post program implementation among study group compared to preprogram implementation. When showed better enhancement in recovery among substance use patients' this will lead to acceptance of the study hypothesis about compliance undergoing motivational interviews training program.

\section{Recommendation}

- Continuous in- service training programs about counseling need to be implemented to provide basic necessary skills.

- Apply the motivational interviewing sessions in addiction centers to provide a better prognosis for substance use.

- Facilitate the access to information for the staff members through the internet, library and digital library.

- Purchasing national and international journals and make it free for staff members to encourage them to be aware of the new topics and trends related to substance use recovery.

\section{References}

Abd Elhamid, M. (2018):Psychosocial Adjustment among substance Abuser during Relation phase of Treatment. Published master thesis in faculty of Nursing. Ain Shams University, Egypt. P.p 98. 
Abu Attia, S. \& El-Hassan, L. (2014):The effectiveness of expective therapy in reducing psychiatric disorders and improving self-esteem and social support among addicts. Journal of Educational sciences studies, 41 (1). P.p.139-161.

Ali, A. (2018): The effect expressive disclosure writing on self-stigma drepression, anxiety and stress among substance dependent. PHD Thesis, Alexandria, Faculty of nursing. Department of psychiatric nursing nursing and mental health.

Almshaqbh, B. (2015): The effect of counseling program in enhancing social skills and reducing addiction behavior among drug addicted individuals Journal of the Islamic Unversity for Educational psychological Studies, 24 (4). Pp.265-291.

Al-Ruwaili, F. \& Al-Shawi, R. (2016): The effect a group counseling program in reducing depression and enhancing selfesteem among drug addicts in Al-Amal hospital in Saudi Arabia. Journal of AlQuds Open University for Educational and psychological research and studies. 4 (13). p.p. 285-310.

Beck, S.(2018): Treating substance misuse with cognitive behavior therapy: Basics and beyond Guilford press.

Best, J. (2018): Nurse Therapist, child and adolescent mental health larkfield child\& Family centre Invercl, director of NHS Gereater Glasgow and Clyde, pioneering the mental health arm of the Scottish patient safety programs.

Chow, Shao \& Wang (2017): Sample size calculations in clinical research $\left(3^{\mathrm{rd}} \mathrm{ed}\right)$, Accessed at (Augast 15, 2017) p.p 358412.
Cleary, M. and Thomas, P. (2017): Addiction and mental across the lifespan: An overview of some contemporary issues.

Crane, A.,Godleski, A., Przbyla, M.,Schlauch, C. and Testa, M. (2016): The proximal effects of acute alcohol consumption on male-to-female aggression: a meta-analytic review of the experimental literature. Trauma, Violence, \& Abuse, 17(5), pp 520-531.

Doostain, Y., Bahman, B., Farhoudain, A., Azkjosh, M. and Khanjani, $M$. (2019): Vocational rehabilitation for individuals with substance-Related disorders. Oranian rehabilitation journal. 17 (2). P.p 105-111.

Farag, Z. (2019): Perceived stigma, selfstigma and social functioning among individuals with substance abuse disorders. Master thesis. Alexandria University, Faculty of nursing. Dpartment of psychiatric nursing and mental health

Fazel, S., Langstrom, N., Hjern, A., Grann, M. \& Lichtenstein, P. (2016): Substance abuse and violent crime. JAMA; 301 (19).

Firestone, M., Smyli, J., Maracle, S., Mcknight, C., Spiller, M. \& O'campo, P. (2015):Mental health and substance use in an urban first nations population in hamilton, Ontario, Canadian Journal of public health, 106 (6): e 375-81. Doi:10.172691 CJPH. 106. 4923. JSTOR 90005913. PMC 6972211. PMID 26680428.

Heidari, M. and Ghodusi, M. (2016):Relationship of assess self-esteem and locus of control with quality of life during treatment stages in patient referring 
to drug addiction rehabilitation centers. Mater Sociomed, 28 (4): P.P.263-267.

\section{Homel, J., Thompson, K. \& Leadbeater, B.} (2015): Trajectories of marijuana use in youth ages: Implications for postsecondary education expriences. Journal of studies on Alcohol and Drugs: 674-683.

Karriker, J., Kinger, L., Witbrodt, J. and Kaskutas, A. (2018): Effects of treatment type on alcohol consumption partially mediated by Alcoholic Anonymous attrndance. Substance use \& misuse, 53(4), 596-605.

Kaur, D. and Ajinkya, S. (2017): Psychological Impact of adult alcoholism on spouses \& children. Indian Jounal of psychiatry ;7 (2) pp.124-127.

Limberger, J. and Andretta, I. (2018): Social skills training for drug users under treatment: a pilot study with follow- up. Psicologia: Reflexao e critica, 31(29). Pp.2-10.

Miller, E., Rollnicks, R., Goldestein, S., Mccauley, H., et al. (2016): A school health center intervention for abusive adolescent realationships: a cluster RCT. Pediatrics; 135 (1):76-85.

Morre, B. \& Fine, B. (2015): A Glossary of psychoanalytic terms and concepts, Amer psychoanalytic assn., 6 (78). Online ISBN 978-0-318-13125-2.

Neale, E., J., Vitoratou, S., Finch, E., Lennon, P., Mitcheson, L., Panebianco, D., Strang, J., Wykes, T. \& Marsden, J. (2016): Development and validation os SURE; A patient reported outcome measure (PROM) for recovery from drug and alcohol dependence; Drug and Alcohol Dependence.
Pullen, E. \& Oser, C. (2014):Barriers to substance abuse treatment in rural and urban communities: Counselor perspectives. Substance use \& misuse. 49 (7): $\quad$ 891-901. Doi: 10.31091 10826084.2.2014.891615. PMC 3995852. PMID 24611820.

Reitan, T. (2018): Substance abuse: a 5-year follow- up of mothers and children. Drug: Education, prevention and policy, pp 1-10.

Robinson, C. \& Mayer, K. (2017): Painkillers \& Warning signs of addiction ( $5^{\text {rd }}$ edition), Atlanta library $p$; 844-2253097.

\section{Rollnick, S., Heather, N., Gold, R. \& Hall,} W. (1992): Development of a short readiness to change questionnaire for use in a brief, opportunistic interventions among excessive drinks, British journal of addiction 74 .

Volkow, N., Koob, G. \& Mclellan, A. (2016): Neurobiologic advances from the brain disease model of addiction. New England journal of medicine. 374 (4): 363-371. Doi:10.10561 NejJMra 1511480. PMC 6135257.PMID 26816013.

Whitesell, M., Bachand, A., Pell, J. \& Brown, M. (2018): Familial social and individual factors contributing to risk for substance use, Journal of addiction. Available at Http llwww, Hindawi 1 com. Journals 1 Jad 1 20181579L310, accessed on June 2012018

\section{World Health Organization substance} Abuse, (2018): World helth organization; https: 1lWWW.Who.intol substance abusel publication global- alcohol -reportl en.Accessed November 13, 2019. 


\section{تأثير البرنامج التدريبى للمقابلات التحفيزية على الألتزام بالعلاج بين مرضى تعاطى المخدرات} ايمان محمد الاغار - منى حسن عبدالعال- ميرفت حسني شلبي- منى محمد بركات

المقابلات التحفيزية هي واحدة من التاخلات العلاجية مع بعض الأدلة التى تدعم الفاعلية للحد من تعاطى المخدرات دن خلال تأثير ها، يتم توجيه المعالج للشخص المتعاطى لتحديد المشكلة واتخاذ القرارات بشأن المستقبل بالأضافة إلي أستخدام العلاجات النفسية والأجتماعية الداعمة كمساعدات للعلاج وبرامج التنقيف النفسى أيضا للتخفيف من الأعراض. تهدف هذه الدراسة إلي تقييم مدى تأثثر البرنامج التدريبى للمقابلات التحفيزية على الالتز ام بالعلاج بين مرضى تعاطى المخدرات ، تم إجر اء الدراسة في مستشفى العباسية للصحة العقلية في مدينة القاهرة، وايضا مستشفى الصحة النفية و الأدمان في مدينة ينها بمحافظة القليوبية، تم تحديد عينة مناسبة للدر اسة مقسمة إلي مجموعتين متساويتين وهم مجمو عة در اسة ومجمو عة ضابطة، تم أختيار هم، وتم تقسيم المرضى عن طريق أخذ عينات عشو ائية بسيطة قسمت إلى مجمو عتين متساوتين المجموعة الضابطة

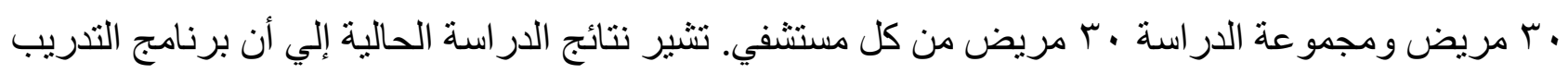
للمقابلات التحفيزية كان لة تأثثر ايجابى على التغيير والأمتثال والألتزام بالعلاج. كما أوصت الدر اسة بأهمية تطبيق جلسات المقابلات التحفيزية فى مر اكز الأدمان لتوفير تشخيص أفضل لتعاطى المخدرات وتوفير مر اكز تأهيل للمتعافين من تعاطى المخدر ات 